\title{
Resenha Direito e Democracia sob os Espectros de Schmitt: contribuição à crítica da filosofia do direito de Habermas
}

\author{
Flavio Riche ${ }^{1}$
}

As reflexões sobre a teoria da democracia têm merecido especial destaque no pensamento contemporâneo. Por certo, a experiência dos regimes totalitários, na primeira metade do século XX, somada ao fim da configuração bipolar do sistema internacional, contribuiu para o fenômeno em questão. Não obstante, sob o termo "teoria da democracia" abriga-se um amplo espectro de autores e ideias, cuja exposição escaparia ao escopo de uma simples resenha.

Pretende-se apenas chamar a atenção para alguns pontos considerados capazes de elucidar a análise da obra e que podem ser encontrados em importantes teóricos hodiernos da democracia.

Primeiramente, é de se notar o questionamento de um postulado caro ao pensamento marxiano, qual seja, a subestimação dos aspectos formais do regime democrático. Ainda que não seja condição suficiente, a dimensão formal constitui uma condição necessária para o efetivo funcionamento de uma democracia.

Ademais, torna-se hoje indesejável, quiçá inconcebível, tentar justificar através de argumentos metafísicos a formulação de leis em regimes democráticos. Seja o procedimento de tomada de decisões no plano inter-

Diplomata de Carreira. Doutorando em Relações Internacionais pela UnB. Mestre em Ciências Jurídicas pela PUC-RIO. Bacharel em Ciências Sociais pela UERJ. Bacharel em Direito pela UNI-RIO. Coordenador do Grupo de Pesquisa Peter Häberle, do Instituto Brasiliense de Direito Público (IDP).E-mail: flavio.riche@itamaraty.gov.br. 
no, seja a formulação de normas com pretensão de universalidade no plano internacional, ambos devem ter como premissa o pluralismo que marca as sociedades complexas contemporâneas - pluralismo este que decorre de um processo de secularização, para o qual contribuíram tanto a Reforma protestante (cujas consequências, sem dúvida, foram além dos objetivos primevos propostos por Lutero) quanto a Revolução científico-filosófica.

Em outras palavras, a intersubjetividade representa o centro de gravidade da noção de deliberação pública, presente mesmo em modelos com teor contrafático, tais como a posição original de John Rawls e a situação ideal de fala de Jürgen Habermas. Não é por acaso que Habermas e Rawls servirão de referência para inúmeros pensadores da democracia deliberativa, como, por exemplo, James Bohman. Avançamos, contudo, mais que o desejado. Voltemos ao tema em questão.

Por fim, a relação entre direito e política inserida no âmbito da justificação democrática do Estado. Justamente aqui reside a maior contribuição da obra de Pablo Guetti, conforme pretendemos demonstrar.

Ao desenvolver uma leitura das obras jurídicas (e principalmente políticas) de Habermas à luz das críticas formuladas por Carl Schmitt (em especial àquelas direcionadas para a democracia liberal burguesa), Ghetti (2006, p. 223) perfila

[...] um caminho teórico que se inscreve no código das emancipações, não no código do poder que investiga a marca, o rastro deixado pela ditadura e pelo fascismo, em suas mais diversas manifestações - do Estado ao Mercado, do Terror fundamentalista e imperial à fé racionalista. E que deixa e cria e reitera, contudo, outra marca, inquieta, não conformista e crítica.

Uma vertente que, no entender do autor, inclui referências como Jürgen Habermas, Jacques Derrida e Chantal Mouffe - não sem as devidas ressalvas.

No que se refere à organização, o texto encontra-se estruturado em dois capítulos centrais. O primeiro, "A militarização da política ou o suicídio da Constituição na obra de Schmitt”, esboça o quadro teórico das 
obras de Schmitt durante o período da República de Weimar, o qual serve de referência para todo o estudo subsequente. Para tanto, é proposta a análise de três eixos de seu pensamento: o eixo da democracia, o eixo da Constituição e o eixo da política. A partir disso, é possível identificar uma espécie de padrão schmittiano: “[...] se ele concede, por um lado, o poder ao povo, defendendo a democracia, por outro, nega e procura controlar toda a força libertária que se pode extrair do exercício da política, do direito e da democracia" (GHETTI , 2006, p. 51).

O segundo capítulo, "Direito e democracia: Habermas contra Schmitt, ou o abandono da política?", ao averiguar os escritos jurídico-políticos de Habermas, é possível identificar respostas aos problemas postos por Schmitt. Assim como no capítulo anterior, trabalha-se a partir da ideia de três eixos basilares, sendo que, no caso habermasiano, a distinção entre democracia, constituição e política mostra-se menos rigorosa. Com rigor analítico, Pablo direciona a discussão para o resgate do político, não apenas identificando a visão de Habermas sobre o entendimento schmittiano a esse respeito, como também avaliando a recepção contemporânea de Schmitt por teóricos da democracia radical.

Como resultado, opta-se, "com Habermas e contra Habermas pela necessidade de afastar/exorcizar o espectro de Schmitt" (GHETTI, 2006, p. 9). Muito embora reconheça o autor pontos de análise comuns entre Schmitt e Habermas - leia-se centralidade do político, primazia da política democrática sobre o direito, limitação da jurisdição constitucional e proteção política da constituição -, afirma ser a alternativa habermasiana dotada de maior plausibilidade, visto que, no lugar da tradição e da autoridade como garantidores da ordem, defende um critério legitimador do direito de índole procedimental, capaz de viabilizar o potencial emancipatório inscrito na força do melhor argumento. Em última instância, trata-se de considerar a Modernidade como um projeto antes que falido, inacabado.

\section{Referências}

GHETTI, Pablo. Direito e democracia sob os espectros de Schmitt: contribuição à crítica da filosofia do direito de Habermas. Rio de Janeiro: Lumen Juris, 2006. 